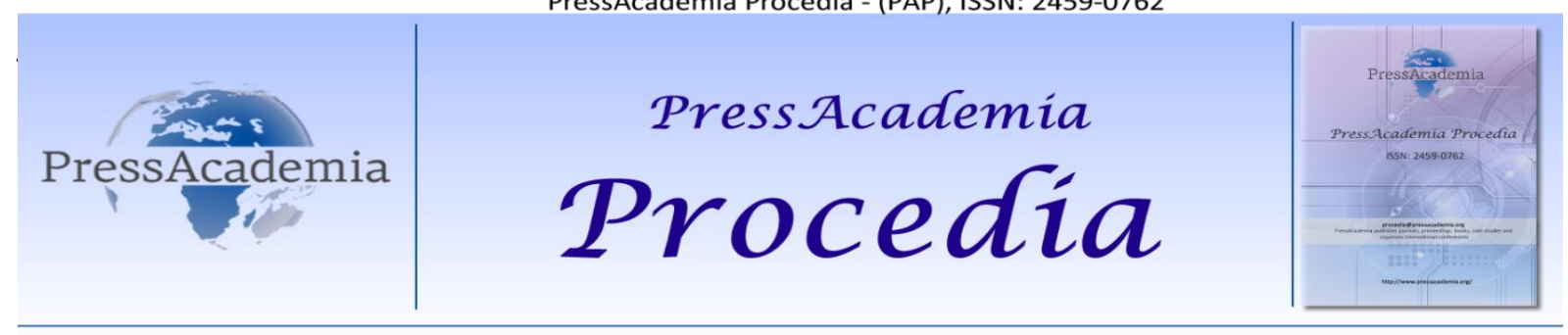

Global Business Research Congress (GBRC), May 24-25, 2017, Istanbul, Turkey.

\title{
A RESEARCH ON THE EFFECT OF USING CELEBRITY ENDORSEMENT IN ADVERTISEMENTS ON PURCHASING DECISIONS OF CONSUMERS
}

DOI: 10.17261/Pressacademia.2017.685

PAP-GBRC- V.3-2017(112)-p.1043-1057

Ece Armagan ${ }^{1}$, Ozden Gursoy ${ }^{2}$

${ }^{1}$ Adnan Menderes Üniversitesi, Department of Business, AYDIN, Turkey. earmagan@adu.edu.tr

${ }^{2}$ Adnan Menderes Üniversitesi, Department of Business, AYDIN, Turkey. o.gursoy 85@ hotmail.com

To cite this document

Armagan, E., and O. Gursoy, (2017). A research on the effect of using celebrity endorsement in advertisements on purchasing decisions of consumers. PressAcademia Procedia (PAP), V.3, p.1043-1057.

Permanant link to this document: http://doi.org/10.17261/Pressacademia.2017.685

Copyright: Published by PressAcademia and limited licenced re-use rights only.

\begin{abstract}
The main purpose of this study is to research the attitudes of consumers on the purchasing decisions of using celebrity endorsement in advertisements published in Turkey. In this study, a questionnaire study was conducted on 482 consumers over 18 years of age residing in Aydın. Statistical analyzes were conducted for the purpose of studying the research data. In the study, it was inspired by Ha \& Lam (2017) and Alsmadi's (2006) Scale of Celebrity Endorsement in Advertisement and hypotheses were tested. In the context of advertising, the importance of consumers' attitudes towards the brand and the effects of their purchasing decisions on the use of the famous dimensions of use in advertising are highlighted. It has been found that the using celebrity endorsement in advertisements has a positive effect on the consumers' purchasing decision and it was detected that the brand remains in the consumer mind for a longer period of time.
\end{abstract}

Keywords: Celebrity endorsement, brand choice, purchasing decision, consumer attitude, advertisement JEL Codes: M30, M31, M37

\section{REKLAMLARDA ÜNLÜ KULLANIMININ TÜKETICILERIN SATIN ALMA KARARINA ETKISI ÜZERINE BİR} ARAŞTIRMA

\section{ÖZET}

Bu araştırmanın temel amacı, Türkiye'de yayınlanan reklamlarda ünlü kullanımının tüketicilerin satın alma kararları üzerindeki tutumlarının incelenmesidir. Bu çalışmada, Aydın ilinde ikamet eden ve kolayda örnekleme yöntemiyle belirlenen 18 yaşüstü 482 tüketici üzerinde anket çalışması yapılmıştır. Araştırma verileriyle çalışmanın amacına yönelik istatistiki analizler gerçekleştirilmiştir. Çalışmada, Ha \& Lam (2017) ve Alsmadi (2006)'nin Reklamlarda Ünlü Kullanımı Ölçeğin'den esinlenilmiş ve hipotezler test edilmiştir. Araştırma kapsamında, reklamlarda ünlü kullanımı boyutlarının tüketicilerin markaya yönelik tutumları ve satın alma kararları üzerindeki etkilerinin önemi ortaya konmuştur. Reklamlarda ünlü kullanımının, tüketicilerin satın alma kararı üzerinde olumlu etkiler yarattığı ve markanın tüketici zihninde daha uzun süre kalıcı olduğu tespit edilmiştir.

Anahtar Kelimeler: Ünlü kullanımı, marka seçimi, satın alma kararı, tüketici tutumu, reklam JEL Kodları: M30, M31, M37 


\section{GíRiş}

Reklamlarda ünlülerin kullanımı, dünya genelinde pazarlamacılar tarafından etkili bir promosyon aracı olarak görülmektedir. Ünlü kullanımı reklamın etkililiğini, markanın tanınması ve hatırlanmasını, satın alma planlarını ve hatta satın alma davranışını etkilemektedir (Spry vd., 2011: 882). Ünlülerin kullanımı uzun süredir kullanılan ve en popüler reklam stratejilerinden biri olup "modern zamanların pazarlamacılığının her yerde bulunan bir özelliği” olarak kabul edilir. Reklamcılar, bir ürünü tanıtmak, kitlenin ilgisini çekmek, ürüne çekicilik ve cazibe katmak ve reklamı daha unutulmaz ve inanılır kılmak için genellikle ünlüleri kullanırlar (Wei ve Lu, 2013: 193).

Bu araştırmanın amacı, reklamlarda ünlü kullanımının tüketicilerin markaya yönelik tutumu ve satın alma niyetiyle ilişkisini ortaya koymaktır. Bu bağlamda öncelikle reklam, ünlü ve ünlü kullanımı kavramlarının tanımları yapıımış, ünlü kullanımının avantaj ve dezavantajları ile literatürdeki ünlü kullanım modellerinden bahsedilmiştir. Daha sonra reklamlarda ünlü

kullanımı boyutlarının tüketicilerin markaya yönelik tutumu ve satın alma niyeti ile ilişkisini açıklamak amacıyla anket ile toplanan verilere dayalı olarak hipotezler test edilmiştir.

\section{LITERATÜR INCELEMESI}

\subsection{Reklam Kavramı}

Reklam, kimliği belirli bir kaynak tarafından gönderilen; bir örgüt, ürün, hizmet ya da fikir hakkında kişisel olmayan ve parası ödenmiş bir iletişim biçimidir (Eser vd., 2011: 53). Tanım ve özellikleri incelendiğinde reklamın bir iletişimde yer alan tüm öğelere sahip olduğu kolaylıkla anlaşılır. Özellikle, kitle iletişimi ve ikna edici iletişim türleri reklamda geçerli olan kavramlardır. Şekil 1'de bu özellik bir süreç içerisinde açıklanmıştır.

\section{Şekil 1: Illetişim Süreci Olarak Reklam}

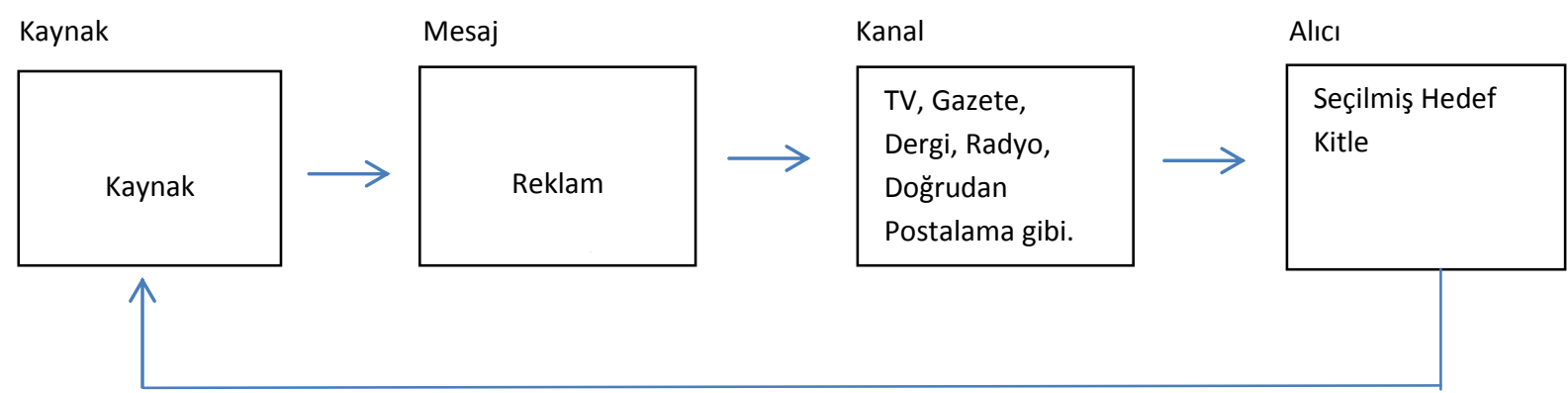

Kaynak: Odabaşı ve Oyman, 2009: 99.

Reklam, daha kapsamlı iletişim faaliyetlerinin sadece tek bir yönünü oluşturur. Alıcılar, deneme yoluyla ürünlerin kalitesini değerlendirebileceğinden imalatçılar ücretsiz ürün numuneleri sunar (Baldauf vd., 2009: 441).

Reklam (Peltekoğlu, 2010: 2);

- Bir iletişim biçimidir, çünkü üretici ve tüketiciyi buluşturmayı amaçlamaktadır,

- Reklamda hem duygu hem mantık vardır, çünkü reklam iletileri bazen rasyonel çoğu zaman duygusal öğelerden oluşur,

- Reklam, yaratıcılık sanatıdır, çünkü amacını gerçekleştirebilmek için oluşturulan ana fikri, hayal gücü kullanılarak, yepyeni bir solukla ve iknanın da gücünden yararlanarak yeniden sunmaktır.

\section{2. Ünlü Kullanımı}

Ünlüler, kamuoyunun tanıdığı ve genellikle çekicilik ya da güvenilirlik gibi ayırt edici özellikleri olan kişilerdir (Gupta vd., 2015: 35). Ünlü, ürün sınıfı ile ilgisi olmayan alanlarda başarılarıyla kamuoyunun tanıdığı bir kişidir (Sertoğlu, 2014: 67). Ünlü kullanımı, yüksek bir fiyat-üretim maliyeti marjı ve büyük bir müşteri tabanı olan ürünlerde daha yaygın görülür (Malik ve Gupta, 2014: 128). Reklamda ünlü kişi kavramı; toplum tarafından tanınan ve reklamı yapılan ürünle birlikte reklamda yer alarak bu tanınmayı ürün adına kullanan kişi olarak tanımlanmaktadır. Reklamda tanınan kişinin kullanımı dikkat çekme, marka kişiliği hakkında ipucu verme ve tüketicilerin zihninde yer etme gibi etmenlerin yanı sıra hedef kitleyi ikna etme açısından önem taşımaktadır (Deneçli, 2015: 338).

Ünlüler ise kendi kişiliklerini ve imajlarını temsil ettikleri markaya ve ürüne aktararak kendileri ile marka veya ürün arasında bağlantılı bir imaj oluştururlar. Kullanımın başarılı olabilmesi için ünlünün tüketiciye aktarması gereken üç farklı özellik vardır. Bunlar inanııılık, çekicilik ve güçtür; burada inanılırlık ürün(ler)le ilgili bilgi, beceri ve uzmanlıkla ifade edilir, çekicilik 
beğenilirliği, tanınırlığı ve ünlünün markaya veya ürün(ler)e benzerliğini içerir ve güç, alıcının satın alma davranışını etkilemesini sağlar (Bafna, 2016: 220).

Pek çok insan, başarı modelleri olarak ünlülerin değerleri ve yaşam tarzları ile ortak özellikler içermeye özenir. Genellikle belirli arzulanır imajlarla kendi kimlikleri üzerinden öz güvenlerini artırmak üzere ünlülerin davranışlarını örnek almaya, bu davranışlara özenmeye ve hatta bu kişileri taklit etmeye çalışırlar. Bu tip davranışlar ünlülerin konuşma, giyinme, iletişim kurma yöntemlerini ve en önemlisi de marka seçimlerini taklit etmeyi içerir. Bu süreç, insanların zaten kim olduklarından çok kim olmayı umut ettikleri ile ilgili çok şey söyler. Bu durum da ünlü kullanımının gücünü yansıtır; zaten her türlü ürünü tanıtmada ünlülerin kullanılmasının arkasındaki temel sebep de budur (Alsmadi, 2006: 72).

\section{3. Ünlü Kullanımının Avantaj ve Dezavantajları}

Çok sayıda araştırma, ünlü kullanımının reklama yönelik tutum, markaya yönelik tutum ve satın alma niyeti gibi önemli reklam etkinliği ölçütlerini olumlu etkilediğini göstermiştir. Ayrıca ünlü kullanma stratejisinin, anlam aktarımı yoluyla ürün için bir imaj yaratma kapasitesi vardır. Bu avantajlar için şirketler, reklamda ünlülerin markalarını tanıtması için önemli meblağlar ödemeyi kabul etmektedir (Muda vd., 2014: 12). Kuruluşlar, çeşitli nedenlerle ünlüleri kullanır. Şirketler, ünlünün yaşam deneyimlerinin reklamın mesajına uygun olduğunu, şirketin hedef tüketici grubu bağlamında ünlünün yüksek bir cazibesi olduğunu veya ünlünün evrensel çekiciliğinin, reklamı evrensel kıldığını düşünebilir (Mathur vd., 1997: 67).

Ünlü kullanımı avantajları şöyle sıralanabilir: Ürüne dikkat çekmek ve karmaşık reklam kümesinde bile hedef pazara ulaşmak; olumlu özellikleri olan bir ünlü, ünlüye bunu yapmak için ödeme yapıldığının bilinmesine rağmen reklamı yapılan ürünlerin ve hizmetlerin olumsuz algısını değiştirebilir. Doğru ünlü, yeni piyasaya sürülen bir ürün için anında bir konum oluşturabilir veya yanlış konumlanan bir ürünün algısını değiştirebilir. Ünlüler dünyanın her yerinde tanınır ve bu da uluslararası pazarda konumlanan ürüne benzer bir statü verebilir (Waldt vd., 2009: 102).

Ünlü kullanımının avantajları sistematik olarak araştırılmıştır. Örneğin bir vaka çalışmasında, Michael Jordan'ın 1995'te Ulusal Basketbol Birliğine (NBA) dönüşüne dair beklentilerin, Jordan'ın artan görünürlüğü ile birlikte müşteri şirketlerinin pazara ayarlanmış değerlerinde ortalama yaklaşık yüzde iki veya borsa değerinde 1 milyar doların üzerinde bir artış sağladığı rapor edilmiştir (Pornpitakpan, 2003: 179). Ünlü kullanımları şirket açısından pahalıdır. Ünlünün statüsüne bağlı olarak bu rakam, birkaç yıl genelinde milyonlarca dolara ulaşabilir. Sözleşme ayrıca bir kâr paylaşma planı da içerebilir. Şirketler genellikle ünlüler çevresinde özel ve pahalı reklam kampanyaları inşa eder (Agrawal ve Kamakura, 1995: 56). Her ne kadar ünlü kullanmanın potansiyel faydaları önemli olsa da maliyeti ve riskleri de önem taşır. Tablo 1, ünlü kullanma stratejisinin potansiyel avantajlarını ve tehlikelerini göstermenin yanı sıra bazı önleyici taktikler de sunmaktadır (Erdogan, 1999: 295).

Tablo 1: Ünlü Kullanımının Avantaj ve Dezavantajları

\begin{tabular}{|l|l|l|}
\hline Potansiyel Avantajlar & Potansiyel Tehlikeler & Önleyici Taktikler \\
\hline Artan ilgi & Markanın gölgede kalması & Ön-test ve dikkatli planlama \\
\hline İmaj parlaklığı & Kamuoyu tartışmaları & $\begin{array}{l}\text { Sigorta yaptırmak ve sözleşmelerde } \\
\text { hüküm maddeleri koymak }\end{array}$ \\
\hline Marka tanıtımı & $\begin{array}{l}\text { İmaj değişikliği ve gereğinden fazla } \\
\text { teşhir edilmesi }\end{array}$ & $\begin{array}{l}\text { Rollerinin neler olduğunu açıklamak ve } \\
\text { diğer markaların desteklemesini } \\
\text { kısıtlamak için maddeler koymak }\end{array}$ \\
\hline $\begin{array}{l}\text { Markanın yeniden } \\
\text { konumlandırıması }\end{array}$ & $\begin{array}{l}\text { İmaj değişikliği ve halk tarafından } \\
\text { tanınırlığın kaybı }\end{array}$ & $\begin{array}{l}\text { Ünlünün hangi yaşam döngüsünde } \\
\text { olduğunu ve bu döngünün daha ne } \\
\text { kadar sürebileceğini incelemek }\end{array}$ \\
\hline $\begin{array}{l}\text { Küresel kampanyaların } \\
\text { desteklenmesi }\end{array}$ & Pahalı olma durumu & $\begin{array}{l}\text { Küresel hedef kitle için uygun olan } \\
\text { ünlülerin seçilmesi dikkat etmek }\end{array}$ \\
\hline
\end{tabular}

Kaynak: Erdoğan, 1999: 295

\subsection{Literatürde Ünlü Kullanım Modelleri}

Literatür incelendiğinde ünlü kullanımı araştırmaları temelde dört ana modele dayanmaktadır. Bunlar kaynak güvenilirliği (inanırlı̆ıı), kaynak çekiciliği, ürün - ünlü uyumu ve anlam transferi modelleridir.

\subsubsection{Kaynak Güvenilirliği (İnanırlığı) Modeli}

Güvenilirlik, uzmanlık, dinamizm, nesnellik, emniyet, kalifikasyon, yetkinlik, çekicilik, beğenilirlik, yetkililik, karakter, inanılırlık ve sosyallik gibi çeşitli boyutlar içermesi ile kaynak inanılırlığ kullanılır. Sorun, bu çalışmaların büyük bir kısmının, 
kaynak inanılırlığını ölçmeye yönelik kendi ölçeklerinin güvenilirliğini ve geçerliliğini değerlendirmemesi ve farklı kullanımların, çalışmalar genelinde sonuçları karşılaştırmayı zorlaştırmasıdır (Pornpitakpan, 2003: 180). Kaynak İnanılırlığı Modeli, mesajın etkinliğinin tanıtan kişinin algılanan uzmanlık seviyesine, güvenilirliğine ve çekiciliğine bağlı olduğunu ileri sürer. İnanılır bir kaynaktan (örneğin ünlüden) gelen bilgi, alıcının kendi kişisel tutumu ve değer yapıları bağlamında bir kaynağın etkisini kabul ettiğinde meydana gelen içselleştirme adı verilen bir süreçle inançları, fikirleri, tutumları ve/veya davranışı etkileyebilir (Wang vd., 2017: 11).

Kaynak inanılırlığı, "iletişimcinin, alıcının bir mesajı kabul edişini etkileyen olumlu özellikleri” olarak tanımlanır. Kaynak inanılırlığı modeli, iletişimcinin algılanan inanılırlığını sağlayan faktörleri analiz eder. Model, mesajın etkinliğinin, tanıtıcının veya iletişimcinin algılanan uzmanlık ve güvenilirlik seviyesine bağlı olduğunu ileri sürer. Birlikte değerlendirildiğinde uzmanlık ve güvenilirliğin, kaynak inanılırlığı yapısını bünyesinde barındırdığı varsayılabilir (Amos vd., 2008: 214).

Uzmanlık, kaynağın geçerli savlarda bulunma ile ilgili algılanan becerisi olarak tanımlanır. Güvenilirlik, kaynağın geçerli savlarda bulunma ile ilgili algılanan istekliliği olarak tanımlanır (McCracken, 1989: 311). Güvenilirlik, tanıtıcının dürüstlüğünü, karakter bütünlüğünü ve inanılırlığını ifade eder. Hedef kitlenin algılarına bağlıdır. Reklamcılar, genel olarak dürüst, inanılır olan ve güven telkin eden kişileri seçerek güvenilirlik değerinden yararlanırlar (Erdoğan, 1999: 297).

Kaynak inanılırlığının ikinci önemli boyutu olan uzmanlık ise, iletenin ne ölçüde geçerli iddiaların kaynağı olarak algılandığına işaret etmektedir. Genel bir anlatımla, ünlü kişinin sahip olduğu bilgi, tecrübe veya beceriler olarak ifade edilebilen uzmanlık, "otorite olma" , "yetkinlik", "uzmanlık" ve "nitelik" i temsil etmektedir (Yıldırım vd., 2014: 3).

Çekicilik, kaynak inanııılığının bir diğer önemli bileşenidir. Kişinin kilosu, boyu ve yüz güzelliği ile aktarılan fiziksel çekicilik, başka birisi tarafından algılanan ilk izlenimdir. Bu kavram sadece fiziksel çekicilik anlamına gelmez. Zihinsel beceriler, kişilik, yaşam tarzı ve sanatsal yetenekler de gerektirir. Ünlü bir kişi, kamuoyunda popüler bir imaj inşa ettiği için çekicidir. Bu kişinin çekiciliği, sevdikleri ünlü gibi olmak istedikleri için müşterilere yönelik ikna ediciliği artırır (Ha ve Lam, 2017: 66).

\subsubsection{Kaynak Çekiciliği Modeli}

Kaynak çekiciliği modeli de sosyal psikolojik araştırmaya dayanır. Model, bir mesajın etkinliğinin temel olarak kaynağın "aşinalı̆̆ı", "beğenilirliği" ve/veya "benzerliğine" bağlı olduğunu ileri sürer. Aşinalık, görünür olma yoluyla kaynak hakkında bilgi sahibi olmak; beğenilirlik, kaynağın fiziksel görünümü ve davranışları sonucu kaynağa duyulan duygusal yakınlık; benzerlik ise kaynak ile mesajın alıcısı arasında var olduğu sanılan benzeşim olarak tanımlanır (McCracken, 1989: 311).

The attractiveness model assumes that the effectiveness of the message depends on the physical characteristics of the source, which make it attractive (Chao, Wuhrer, \& Werani, 2005; Till \& Busler, 2000). Acelebrity spokesperson's physical attractiveness has a positive impact on brand recall, attitude toward the brand and purchasing intent (Joseph, 1982; Kahle \& Homer, 1985).

Çekicilik modeli, mesajın etkinliğinin kaynağı çekici kılan fiziksel özelliklerine dayandığını varsayar. Ünlü bir marka yüzünün fiziksel çekiciliğinin markayı hatırlama, markaya yönelik tutum ve satın alma niyeti üzerinde olumlu bir etkisi vardır (Fleck vd., 2012: 652).

\subsection{3. Ünlü - Ürün Uyumu}

Ünlü ile ürün arasındaki eşleşme, "uyum hipotezi" terimi ile ifade edilir. Birçok önemli uyum araştırmasında odak noktası, ünlü ile ürün arasında fiziksel çekiciliğe dayalı bir uyum olmuştur (Till ve Busler, 2000: 2).

Genel olarak ünlü imajının aktardığı mesajın ve ürün imajının etkili reklamlarda yakınsaması gerektiğini öne süren bu "uyum hipotezi", ürün imajı ile ünlü imajı arasında çekicilik tabanında bir uyum gerektiğini öne sürer. Reklamda yer alan görsel imgelerin, açık ve sözlü argümanda yer alan bilgilerin üstünde bilgi aktardığını önerir (Kamins, 1990: 5).

\subsubsection{Anlam Transferi Modeli}

Ünlü kullanımı, anlam aktarımının daha genel sürecinin özel bir örneğidir. Bu modele göre tüketici toplumlarda kültürel anlam hareketi için klasik bir yol vardır. Anlam, mevcut kültürün kategorileri ve ilkeleriyle oluşan fiziksel ve sosyal dünyada, kültürel kurulmuş dünyada yerleşik bir şey olarak başlar. Anlam daha sonra tüketici ürünleri ve son olarak da tüketicinin hayatına ilerler. Bu aktarımı kolaylaştıran birçok araç vardır. Anlamların kültürel kurulu dünyadan tüketici mallarına hareketi, reklam ve moda sistemi ile sağlanır. Anlamların tüketici mallarından bireysel tüketiciye hareketi ise tüketicinin çabalarıyla gerçekleşir. Bu sayede anlam, tüketici toplumunda dolaşır (McCracken, 1989: 313).

\subsection{Markaya Yönelik Tutum}

Tutum; nesneler, insanlar ya da olaylar hakkında olumlu ya da olumsuz değerlendirmelerin bir biçimde ifadesidir (İslamoğlu ve Altunışık, 2013: 134). Tüketicilerin markaya yönelik tutumu o markaya karşı olan duygu derecesinin ölçümüdür. Reklamı 
yapılan markaya karşı olan olumlu ya da olumsuz olan tavırların, satın alma niyetine etkisin oldukça yüksektir (Can ve Serhateri, 2016: 19). Markaya yönelik tutum, markanın en geniş anlamda tüketiciler tarafından nasıl algılandığına dair yorumlanmasıdır. Marka hakkında tüketicinin zihninde canlanan davranış şekilleri olarak nitelendirilen markaya yönelik tutum, tüketici ile marka arasındaki uyumun sağlanması ve satın almaya niyetinin ortaya çıkmasında önemli bir rol oynamaktadır (Öztürk ve Savaş, 2014: 6113).

Markaya yönelik tutum, muhtemelen davranışı hayata geçirecek bir şekilde markanın nispeten devamlı, tek boyutlu bir özet değerlendirmesidir. Bir ünlünün ürün veya markada kullanımının etkisi üzerinde çok sayıda araştırma yapılmış, ünlü kullanımının ürün ve marka tutumları üzerinde bir etki yarattığı ortaya konmuştur. Çalışmalar ayrıca marka tutumunun, müşterilerin satın alma niyetleri üzerinde olumlu bir etkisi olduğunu da öne sürmektedir (Wang, 2017: 12).

\subsection{Satın Alma Niyeti}

Tüketicinin satın alma sürecinde karar aşaması ile iç içe olan satın alma niyeti, mevcut ve yeni ürünlerin satışlarının tahmin edilmesinde sıklıkla kullanılmakta ve işletmelerce satın alma niyetine ilişkin olarak düzenli veri toplanmaktadır. Toplanan bu verilerle talep tahminleri yapılmakta ve bunlara dayalı olarak bir takım stratejik kararlar alınmaktadır. Genel olarak bir ürünü satın alma eğilimi olarak tanımlanabilecek satın alma niyeti, tüketicinin bir ürünü gelecek dönemlerde satın almasına yönelik istekliliği çerçevesinde ölçülmüştür (Mutlu vd., 2011: 55).

Müşterinin satın alma niyeti, belirli bir marka veya ürünü satın almaya yönelik eğilimi ile ilgilidir. Satın alma niyeti ayrıca bir kişinin bir ürünü satın alma intimali hakkında da bilgi verir. Amos vd., (2008), müşterinin ünlü kullanımına yönelik olumlu tutumunun, satın alma niyetini iyileştireceğini öne sürer. Çok sayıda çalışma ayrıca müşterinin markaya yönelik tutumunun, satın alma niyeti üzerinde olumlu ve önemli bir etkisi olduğunu da ortaya koymaktadır (Ha ve Lam, 2017: 67).

\section{VERI VE YÖNTEM}

Reklamlarda ünlü kullanımı konusunda yapılan çalışmalarda çoğunlukla anket yönteminin kullanıldığı tespit edilmiştir. Ana kütle sayısının bilinmediği durumlarda kullanılan örneklem büyüklüğü tesbitine göre örneklem sayısı minimum 384'tür (Altunışık vd., 2007: 127). Araştırma örnekleminin belirlenmesinde, maliyet ve zaman kısıtlarından kolayda örnekleme yöntemi seçilmiş olup, Aydın il merkezinde yaşayan 18 yaş üzeri 482 adet tüketiciye anket yapılmıştır. Araştırma modelinin geliştirilmesinde Alsmadi (2006) ve $\mathrm{Ha}$ ve Lam (2017)'ın çalışmalarından yararlanılmıştır. Anket soru formunun oluşturulmasında, çeşitli çalışmalardan yararlanılmıştır (Alsmadi, 2006; Kurtbaş ve Barut, 2010; ve Erkal, 2013; Albar ve Öksüz, 2013; Bafna, vd., 2016; Ha ve Lam, 2017; Wang, vd., 2017).

Anketin birinci bölümünde, tüketicilerin demografik özelliklerine yönelik sorular, ikinci bölümünde ise reklamlarda ünlü kullanımının tüketicilere çekicilik, güvenilirlik, ünlünün uzmanlığı ve ünlü-ürün uyumu konusundaki etkileri, ünlü kullanımının tüketicilerin markaya olan tutumlarını ve markayı satın alma niyetini ölçmeye yönelik ifadeler yer almıştır. Değerlendirme 5’li likert ölçeği aracılığı ile gerçekleştirilmiştir. Ölçekte 1“kesinlikle katılmıyorum”, 5 ise "kesinlikle katılıyorum"a karşılık gelmektedir. Araştırma verilerinin istatistiksel analizinde, SPSS 20 paket programı kullanılmıştır.

\subsection{Araştırmanın Modeli ve Hipotezler}

\section{Şekil 2: Araştırmanın Modeli}

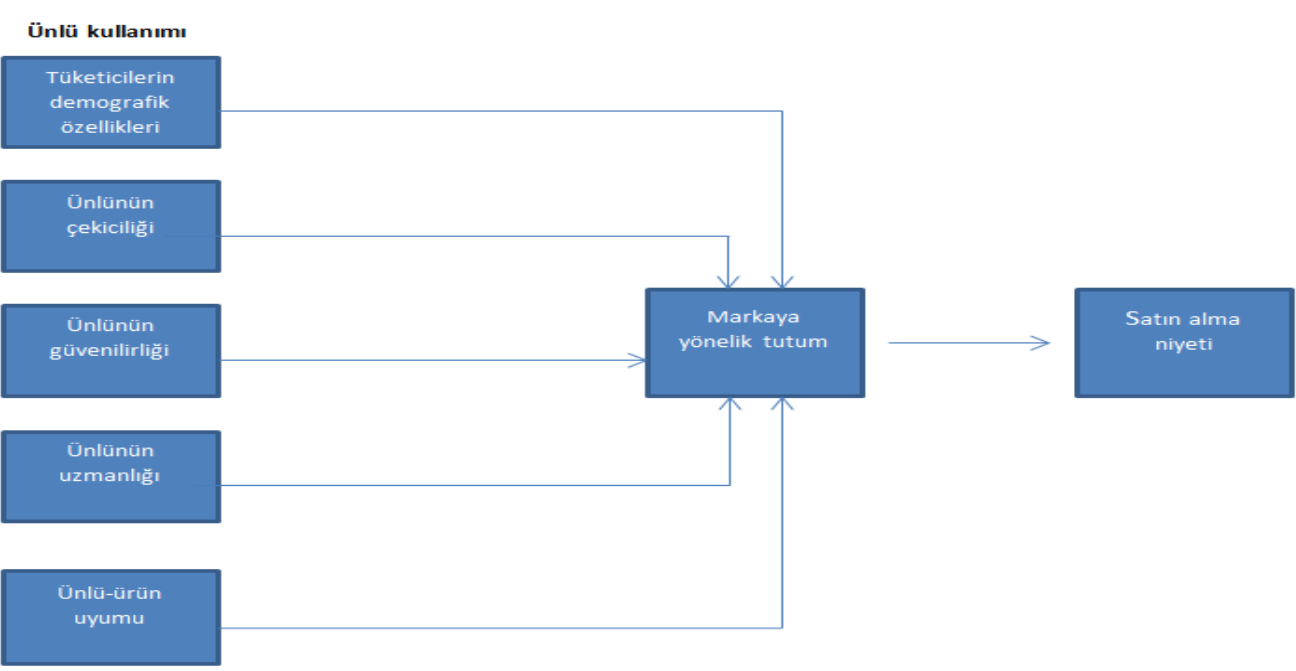




\section{Hipotezler}

H1: Tüketicilerin demografik özellikleri ile reklamlarda ünlü kullanımı algıları arasında fark vardır.

$\mathrm{H}_{2}$ : Tüketicilerin demografik özellikleri ile markaya yönelik tutumları arasında fark vardır.

$\mathrm{H}_{3}$ : Tüketicilerin demografik özellikleri ile satın alma niyetleri arasında fark vardır.

$\mathrm{H}_{4}$ : Tüketicilerin reklamda ünlü kullanımı algısı ile markaya yönelik tutumları arasında anlamlı bir ilişki vardır.

H5: Tüketicilerin reklamda ünlü kullanımı algısı ile satın alma niyetleri arasında anlamlı bir ilişki vardır.

H6:Tüketicilerin markaya yönelik tutumlarıyla ile satın alma niyetleri arasında anlamlı bir ilişki vardır.

Reklamlarda ünlü kullanımını etkileyen 4 faktör ele alınmıştır. Bu faktörler bağımsız değişkenler olup, ünlünün çekiciliği, ünlünün güvenilirliği, ünlünün uzmanlığı ve ünlü - ürün uyumu olarak ayrılmıştır. Tüketicinin markaya yönelik tutumu ara değişken, satın alma niyeti ise bağımlı değişken olarak belirlenmiştir.

\subsection{Güvenilirlik (Reliability) Analizi}

Ölçümün güvenirliğini test etmek için Cronbach's Alpha uygulanmıştır. Ölçeğin geneline uygulanan ilk güvenirlik analizinde ÜK23 numaralı ifadenin çıkarılmasıyla ölçek güvenirliğinin artacağı görülmüş ve ifade ölçekten çıkarılarak Cronbach's Alpha değeri 0,955 (\%95,5) olarak bulunmuştur. Çalışmamızda bulunan Cronbach's Alpha değeri de yüksek güvenirlikte çıkmıştır. Tablo 2'de toplamdaki tüm soruların ve her bir değişkene ait olan soru gruplarının bireysel olarak güvenilirlik analiz sonuçları gösterilmektedir.

Tablo 2: Güvenilirlik Analizi Sonucu

\begin{tabular}{|l|c|c|c|}
\hline Değişkenler & $\begin{array}{c}\text { Uygulanan katılımcı } \\
\text { sayısı }\end{array}$ & Soru Sayısı & Cronbach's Alfa \\
\hline Reklamda ünlü kullanımı & 482 & 18 &, 934 \\
Markaya yönelik tutum & 482 & 6 &, 859 \\
Satın Alma Niyeti & 482 & 4 &, 886 \\
Tüm ölçek & 482 & 28 &, 955 \\
\hline
\end{tabular}

\section{BULGULAR VE TARTIŞMA}

Araştırma kapsamındaki tüketicilerin yaş, cinsiyet, medeni durum gibi demografik özellikleri ile alışverişi ilk sırada etkileyen faktörlere dair sayı ve yüzdeleri ortaya konmuştur.

Tablo 3: Katılımcıların Sosyo-Demografik Özellikleri

\begin{tabular}{|c|c|c|c|c|c|}
\hline & Sayı & $\%$ & & Sayı & $\%$ \\
\hline Cinsiyet & & & Meslek & & \\
\hline Kadın & 277 & 57,5 & Özel sektör & 94 & 19,5 \\
\hline Erkek & 205 & 42,5 & Kamu çalışanı & 38 & 7,9 \\
\hline Yaş & & & Çalışmıyor & 36 & 7,5 \\
\hline $18-28$ & 316 & 65,6 & Öğrenci & 274 & 57,0 \\
\hline $29-39$ & 119 & 24,7 & Serbest meslek & 25 & 5,2 \\
\hline $40-50$ & 19 & 3,9 & Emekli & 14 & 2,9 \\
\hline $51-61$ & 18 & 3,7 & Gelir & & \\
\hline 62 ve üzeri & 10 & 2,1 & $0-999$ & 258 & 53,5 \\
\hline Medeni Durum & & & $1000-1999$ & 81 & 16,8 \\
\hline
\end{tabular}




\begin{tabular}{|c|c|c|c|c|c|}
\hline Bekar & 369 & 76,6 & $2000-2999$ & 49 & 10,2 \\
\hline Evli & 113 & 23,4 & 3000-3999 & 40 & 8,3 \\
\hline Öğrenim Durumu & & & $4000-4999$ & 20 & 4,1 \\
\hline ilkokul & 5 & 1 & 5000 ve üzeri & 34 & 7,1 \\
\hline Ortaokul & 4 & 0,8 & TV İzleme sıklığı & & \\
\hline Lise & 49 & 10,2 & Hiç izlemiyorum & 154 & 32 \\
\hline Yüksekokul & 135 & 28,0 & 1-2 saat & 219 & 45,4 \\
\hline Lisans & 230 & 47,7 & 3-4 saat & 79 & 16,4 \\
\hline Yüksek Lisans & 44 & 9,1 & 5-6 saat & 19 & 3,9 \\
\hline Doktora & 15 & 3,1 & $7-8$ saat & 4 & 0,8 \\
\hline Kitle iletişim aracı & & & $\begin{array}{l}\text { Sabah kalkıştan akşam } \\
\text { yatıncaya kadar açık }\end{array}$ & 7 & 1,5 \\
\hline TV & 160 & 33,2 & $\begin{array}{l}\text { Alışverişi ilk sırada } \\
\text { etkileyen faktörler }\end{array}$ & & \\
\hline $\begin{array}{l}\text { Gazete vb. basılı } \\
\text { mecra }\end{array}$ & 4 & 0,8 & Marka ismi & 129 & 26,8 \\
\hline Radyo & 6 & 1,2 & Ünlü kullanımı & 74 & 15,4 \\
\hline Internet & 305 & 63,3 & Kalite & 172 & 35,7 \\
\hline Afiş / Bilboard & 7 & 1,5 & Maliyet & 98 & 20,3 \\
\hline \multicolumn{4}{|c|}{\begin{tabular}{|l|l|} 
& Dikkat çekici ambalaj
\end{tabular}} & 9 & 1,9 \\
\hline
\end{tabular}

\subsection{Faktör Analizi}

Geçerliliği ölçmek için yapılan faktör analizinde ise Kaiser-MeyerOlkin (KMO) örnekleme yeterliliği istatistiği 0,93 çıktığından örneklemin faktör analizi yapmak için yeterli düzeyde olduğu, Bartlett Küresellik testine göre anlamlılık 0,000 olduğundan değişkenler arasında faktör analizi yapmaya yeterli düzeyde bir ilişki bulunduğu ortaya çıkmıştır.

Tablo 4: Reklamda Ünlü Kullanımı Ölçeğine Dair Faktör Analizi Sonuçları

\begin{tabular}{|c|c|c|c|c|}
\hline Faktör Adı & Önermeler & Faktör Yükü & $\begin{array}{l}\text { Faktör Açıklayıcılığı } \\
\text { (\%) }\end{array}$ & $\begin{array}{l}\text { Conbach's Alpha } \\
\text { (Güvenirlik } \\
\text { Değeri) }\end{array}$ \\
\hline \multirow{5}{*}{ 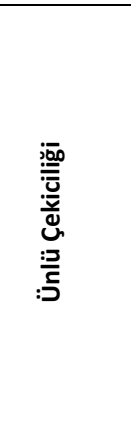 } & $\begin{array}{l}\text { Ünlülerin reklamlarda oynaması dikkatimi } \\
\text { çeker. }\end{array}$ & ,88 & \multirow{5}{*}{47,69} & \multirow{5}{*}{ 912 } \\
\hline & $\begin{array}{l}\text { Ünlü kullanan reklamlar diğer reklamlara } \\
\text { göre daha etkilidir. }\end{array}$ & ,86 & & \\
\hline & $\begin{array}{l}\text { Ünlülerin reklamlarda oynaması dikkat } \\
\text { çekicidir. }\end{array}$ & 90 & & \\
\hline & $\begin{array}{l}\text { Ünlülerin reklamlarda rol alması reklamı } \\
\text { daha keyifli hale getirir. }\end{array}$ & ,82 & & \\
\hline & $\begin{array}{l}\text { Reklamlarda etkili ünlü seçimi ürün } \\
\text { detaylarına daha çok odaklanmamı sağlar. }\end{array}$ & ,70 & & \\
\hline
\end{tabular}




\begin{tabular}{|c|c|c|c|c|}
\hline \multirow{4}{*}{ 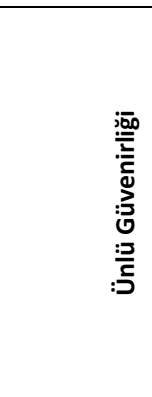 } & \multirow{2}{*}{$\begin{array}{l}\text { Genel olarak reklamda kullanılan ünlünün } \\
\text { marka seçimine güvenirim. } \\
\text { Genel olarak kullanılan ünlünün güvenilir } \\
\text { olduğunu düşünürüm. }\end{array}$} & ,75 & \multirow{4}{*}{13,73} & \multirow{4}{*}{,902 } \\
\hline & & 81 & & \\
\hline & $\begin{array}{l}\text { Genel olarak reklamda kullanılan ünlünün } \\
\text { insanlara güvenilir bilgi kaynağı sunduğunu } \\
\text { düşünürüm }\end{array}$ & ,71 & & \\
\hline & $\begin{array}{l}\text { Genel olarak reklamda kullanılan ünlünün } \\
\text { dürüst olduğunu düşünürüm. }\end{array}$ & ,68 & & \\
\hline \multirow{4}{*}{ 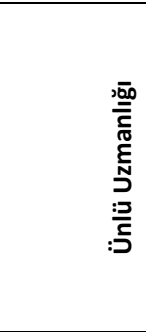 } & $\begin{array}{l}\text { Ünlü kişinin kendi alanında uzman olduğunu } \\
\text { düşünürüm. }\end{array}$ & ,83 & \multirow{4}{*}{7,79} & \multirow{4}{*}{ 907 } \\
\hline & $\begin{array}{l}\text { Ünlü kişinin markayı kullanmada tecrübesi } \\
\text { olduğunu düşünürüm. }\end{array}$ & 73 & & \\
\hline & $\begin{array}{l}\text { Ünlü kişinin marka hakkında bilgi sahibi } \\
\text { olduğunu düşünürüm. }\end{array}$ & 74 & & \\
\hline & $\begin{array}{l}\text { Ünlü kişinin mesleki becerilerinin yüksek } \\
\text { olduğunu düşünürüm. }\end{array}$ & ,74 & & \\
\hline \multirow{4}{*}{ 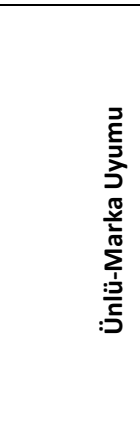 } & $\begin{array}{l}\text { Reklamlarda oynayan ünlünün karakteri } \\
\text { markanın imajını etkiler. }\end{array}$ & ,61 & \multirow{4}{*}{4,97} & \multirow{4}{*}{,917 } \\
\hline & $\begin{array}{l}\text { Reklamlarda yer alan ünlüyle markanın } \\
\text { arasındaki uyum ne kadar fazlaysa markaya } \\
\text { olan güven o kadar artar. }\end{array}$ & ,64 & & \\
\hline & $\begin{array}{l}\text { Bir markanın reklamlarda hep aynı ünlüyü } \\
\text { oynatması ünlüyle markanın özdeşleşmesini } \\
\text { sağlar. }\end{array}$ & 84 & & \\
\hline & $\begin{array}{l}\text { Reklamlarda oynayan ünlünün o markayı } \\
\text { temsil ettiğini düşünürüm. }\end{array}$ & ,82 & & \\
\hline \multicolumn{3}{|l|}{ TOPLAM } & 74,19 & \\
\hline \multicolumn{4}{|c|}{ Cronbach Alpha Değeri (17 değişken için) } & ,929 \\
\hline \multicolumn{4}{|c|}{ Kaiser-Meyer-Olkin (KMO) Örneklem Yeterliliği (17 değişken için) } & 925 \\
\hline \multicolumn{3}{|c|}{ Bartlett Küresellik Testi } & Ki-kare & 5814,228 \\
\hline
\end{tabular}

Ölçekte yer alan 18 ifadeden ÜK6 ifadesi birden fazla faktöre yükleme yaptığı için ölçekten çıkarılmış ve ifadeler tekrar faktör analizine tabi tutulmuştur. 17 ifadeden oluşan 4 alt boyut tespit edilmiştir. Tablo 4'de ölçeklerin alt boyutları, faktör yükleri (yoğunlukları) ve Cronbach's Alpha katsayıları yer almaktadır. 4 faktörün toplam varyansın \% 74,19'nu açıkladığı belirlenmiştir. Tablo 4'e bakıldığında birinci faktör 5 , ikinci faktör 4 , üçüncü faktör 4 , dördüncü faktör ise 4 soruyu içermektedir. Başka bir deyişle, birinci faktör beş, ikinci faktör dört, üçüncü faktör dört, dördüncü faktör dört soruda en yüksek faktör yoğunluklarına sahiptir.

“Ünlülerin reklamlarda oynaması dikkat çekicidir” ifadesi, hem birinci faktör içinde hem de tüm ifadelerin içinde en yüksek faktör yüküne sahip $(0,90)$ olan ifadedir. "Ünlülerin reklamlarda oynaması dikkatimi çeker" ifadesi, hem birinci faktör içinde hem de tüm ifadelerin içinde en yüksek ikinci faktör yüküne $(0,88)$ sahip olan ifadedir. "Ünlü kullanan reklamlar diğer reklamlara göre daha etkilidir" ifadesi, hem birinci faktör içinde hem de tüm ifadelerin içinde en yüksek üçüncü faktör yüküne $(0,86)$ sahip olduğu görülmektedir. Sonuçlara bakılduğı zaman ünlü kullanılan reklamların diğer reklamlara göre daha dikkat çekici ve etkili olduğu, insanların da daha çok dikkatini çektiği sonuçlarına varıldığı söylenebilir.

\subsection{T Testi ve One-Way Anova Testi}

Çalışmanın bu kısmında tüketicilerin cinsiyet, medeni durum ve diğer demografik özelliklerinin reklamlarda ünlü kullanımı algılarına, markaya karşı tutumlarına ve satın alma niyetlerine olan etkilerini belirlemeye yönelik t testleri ve anova testleri yapılmıştır.

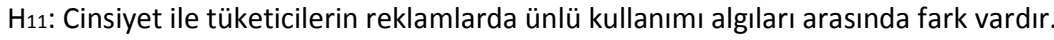

$\mathrm{H}_{12}$ : Medeni durum ile tüketicilerin reklamlarda ünlü kullanımı algıları arasında fark vardır.

$\mathrm{H}_{21}$ : Cinsiyet ile tüketicilerin markaya yönelik tutumları arasında fark vardır. 
$\mathrm{H}_{22}$ : Medeni durum ile tüketicilerin markaya yönelik tutumları arasında fark vardır.

$\mathrm{H}_{31}$ : Cinsiyet ile tüketicilerin satın alma niyeti arasında fark vardır.

H32: Medeni durum ile tüketicilerin satın alma niyeti arasında fark vardır.

Tablo 6: Cinsiyet ve Medeni Duruma Göre Faktörlerin, Ara Değişken ve Bağımlı Değişkenin Değerlendirilmelerine ilişsin tTesti Tablosu

\begin{tabular}{|c|c|c|c|c|c|c|c|c|c|c|}
\hline & Kadın & Erkek & $t$ & df & Sig & Bekar & Evli & $t$ & df & Sig \\
\hline $\begin{array}{l}\text { Ünlünün } \\
\text { çekiciliği }\end{array}$ & 3,0848 & 3,0268 & ,584 & 480 & ,560 & 3,1310 & 2,8289 & 2,623 & 480 & ,009* \\
\hline $\begin{array}{l}\text { Ünlünün } \\
\text { güvenilirliği }\end{array}$ & 2,2960 & 2,2939 & ,022 & 480 & ,982 & 2,3530 & 2,1062 & 2,219 & 480 & ,027* \\
\hline $\begin{array}{l}\text { Ünlünün } \\
\text { uzmanlığı }\end{array}$ & 2,5063 & 2,5329 &,- 289 & 480 & ,773 & 2,5854 & 2,2965 & 2,705 & 480 & ,007* \\
\hline $\begin{array}{l}\text { Ünlü-ürün } \\
\text { uyumu }\end{array}$ & 3,2473 & 3,2646 & -190 & 480 & ,850 & 3,2419 & 3,2965 &,- 512 & 480 & 609 \\
\hline $\begin{array}{l}\text { Reklamda } \\
\text { ünlü } \\
\text { kullanımı }\end{array}$ & 2,8269 & 2,8086 & ,236 & 480 & ,814 & 2,8658 & 2,6668 & 2,207 & 480 & ,028* \\
\hline $\begin{array}{l}\text { Markaya } \\
\text { yönelik } \\
\text { tutum }\end{array}$ & 3,0361 & 3,0014 & ,526 & 480 & ,599 & 3,0465 & 2,9393 & 1,393 & 480 & 164 \\
\hline $\begin{array}{l}\text { Satın } \\
\text { alma } \\
\text { niyeti }\end{array}$ & 2,2879 & 2,3085 &,- 218 & 480 & ,828 & 2,3936 & 1,9801 & 3,799 & 480 & ,000* \\
\hline
\end{tabular}

Tablo 6'ya bakıldığı zaman cinsiyet ile tüketicilerin reklamlarda ünlü kullanımı algısı boyutları, markaya yönelik tutumları ve satın alma niyetleri arasında anlamlı bir ilişkinin bulunmadığı görülmektedir. Bu yüzden $H_{11}, H_{21}$ ve $H_{31}$ hipotezleri reddedilmiştir $(p>0,05)$. Tüketicilerin medeni durumu ile reklamda ünlü kullanımı arasında anlamlı bir ilişki vardır iddasının doğru olduğu $(0,028<0,05)$ ve $\mathrm{H}_{12}$ hipotezinin kabul edildiği görülmektedir. Ortalamalara bakıldığı zaman bekar olan katılımcıların $(2,8658)$, evli olan katılımcılara $(2,6668)$ nazaran reklamda ünlü kullanımı algısına olan ilgisinin daha yüksek olduğu söylenebilir. Test sonucuna bakıldığında tüketicilerin medeni durumlarıyla satın alma niyeti arasında anlamlı bir ilişki vardır hipotezi $\left(\mathrm{H}_{32}\right)$ kabul edilmiştir. Bekar olan katılımcıların $(2,3936)$, evli olan katılımcılara göre $(1,9801)$ reklamda ünlü kullanımı algıları konusunda daha hassas oldukları sonucuna varılabilir. $\mathrm{H}_{22}$ hipotezine bakıldığı zaman $\mathrm{p}$ değerinin $0,050^{\prime}$ den büyük olmasından dolayı hipotezin reddedildiği ortaya çıkmıştır $(0,164>0,050)$.

H13: Yaş ile tüketicilerin reklamlarda ünlü kullanımı algıları arasında fark vardır.

$\mathrm{H}_{14}$ : Öğrenim durumu ile tüketicilerin reklamlarda ünlü kullanımı algıları arasında fark vardır.

H15: Meslek ile tüketicilerin reklamlarda ünlü kullanımı algıları arasında fark vardır.

H16: Gelir ile ile tüketicilerin reklamlarda ünlü kullanımı algıları arasında fark vardır.

$\mathrm{H}_{17}$ : Alışverişleri ilk sırada etkileyen faktör ile reklamlarda ünlü kullanımı algıları arasında fark vardır.

$\mathrm{H}_{23}$ : Yaş ile tüketicilerin markaya yönelik tutumları arasında fark vardır.

H24: Öğrenim durumu ile tüketicilerin markaya yönelik tutumları arasında fark vardır.

$\mathrm{H}_{25}$ : Meslek ile tüketicilerin markaya yönelik tutumları arasında fark vardır.

$\mathrm{H}_{26}$ : Gelir ile ile tüketicilerin markaya yönelik tutumları arasında fark vardır.

$\mathrm{H}_{27}$ : Alışverişlerinizi ilk sırada etkileyen faktör ile tüketicilerin markaya yönelik tutumları arasında fark vardır.

$\mathrm{H}_{33}$ : Yaş ile tüketicilerin satın alma niyetleri arasında fark vardır.

$\mathrm{H}_{34}$ : Öğrenim durumu ile tüketicilerin satın alma niyetleri arasında fark vardır.

$\mathrm{H}_{35}$ : Meslek ile tüketicilerin reklamlarda ünlü kullanımı algıları arasında fark vardır.

$\mathrm{H}_{36}$ : Gelir ile ile tüketicilerin satın alma niyetleri arasında fark vardır.

$\mathrm{H}_{37}$ : Alışverişleri ilk sırada etkileyen faktör ile tüketicilerin satın alma niyetleri arasında fark vardır. 
Tablo 7: Tüketicileri Diğer Demografik Özelliklerine Göre Faktörlerin, Ara Değişken ve Bağımlı Değişkenin Değerlendirilmelerine ilişkin Anova Testi

\begin{tabular}{|c|c|c|c|c|c|c|c|c|c|c|}
\hline & \multicolumn{2}{|c|}{ Yaş } & \multicolumn{2}{|c|}{$\begin{array}{l}\text { Öğrenim } \\
\text { durumu }\end{array}$} & \multicolumn{2}{|c|}{ Meslek } & \multicolumn{2}{|c|}{ Gelir } & \multicolumn{2}{|c|}{$\begin{array}{c}\text { Alıverişi } \\
\text { Etkileyen illk } \\
\text { Sıradaki } \\
\text { Faktör }\end{array}$} \\
\hline & $\mathrm{F}$ & sig & $\mathrm{F}$ & sig & $\mathrm{F}$ & Sig & $\mathrm{F}$ & sig & $\mathrm{F}$ & sig \\
\hline $\begin{array}{l}\text { Ünlünün } \\
\text { çekiciliği }\end{array}$ & 6,056 &, $000 *$ & 5,673 & .133 & 3,609 & ,003* & 3,737 &, $003 *$ & 3,353 & ,010* \\
\hline $\begin{array}{l}\text { Ünlünün } \\
\text { güvenilirliği }\end{array}$ & 4,464 &, $002 *$ & 3,166 &, $005^{*}$ & 3,570 & $.004 *$ & 1,193 & ,091 & 2,670 & $.032 *$ \\
\hline $\begin{array}{c}\text { Ünlünün } \\
\text { uzmanlığı }\end{array}$ & 5,226 &, $000 *$ & 1,950 & ,071 & 5,245 & ,000* & 4,174 &, $001 *$ & 3,529 & ,007* \\
\hline $\begin{array}{c}\text { Ünlü-ürün } \\
\text { uyumu }\end{array}$ & 8,461 &, $000 *$ & 1,589 & 148 & 1,941 & .086 & 1,225 & 296 & 2,200 & ,068 \\
\hline $\begin{array}{l}\text { Reklamda ünlü } \\
\text { kullanımı }\end{array}$ & 7,627 &, $000 *$ & 3,871 &, $001 *$ & 3,565 & ,004* & 3,721 &, $003 *$ & 3,308 & ,011* \\
\hline $\begin{array}{c}\text { Markaya yönelik } \\
\text { tutum }\end{array}$ & 6,180 &, $000 *$ & 1,915 & ,077 & 2,632 & ,023* & 3,372 &, $005 *$ & 3,723 & $.005^{*}$ \\
\hline $\begin{array}{l}\text { Satın alma } \\
\text { niyeti }\end{array}$ & 5,732 & $.000 *$ & 1,900 & .079 & 4,614 & $.000^{*}$ & 2,866 & $.015^{*}$ & 3,171 & $.014^{*}$ \\
\hline
\end{tabular}

Yapılan One-way Anova Testi sonuçlarına bakıldığında $\mathrm{H}_{24}(0,077>0,050)$ ve $\mathrm{H}_{34}(0,079>0,050)$ hipotezlerinin reddedildiği görülmektedir. Tüketicilerin öğrenim durumlarıyla markaya yönelik tutumları ve satın alma niyetleri arasında anlamlı bir ilişkiye rastlanılmamıştır. Katılımcıların öğrenim durumlarıyla reklamlarda ünlü kullanım algısı arasında anlamlı bir farklılık olduğu tespit edilmiş olup, $\mathrm{H}_{14}(0,001<0,050)$ hipotezinin kabul edildiği görülmektedir. İlişkileri değerlendirmedeki farklılıkların yönünü saptamak için Tukey testi yapılmıştır. Sonuçlara bakıldığında öğrenim durumu yüksekokul olan tüketicilerin reklamlarda ünlü kullanımı akgıları, öğrenim durumu lise ve yüksek lisans olan tüketicilere göre daha yüsektir. Tüketicilerin yaş gruplarıyla reklamda ünlü kullanımı algısı, markaya yönelik tutumları ve satın alma niyetleri arasında anlamlı ilişkiler bulunmuştur. $\mathrm{H}_{13}(0,000<0,050), \mathrm{H}_{23}(0,000<0,050)$ ve $\mathrm{H}_{33}(0,000<0,050)$ hipotezleri kabul edilmiştir. Tukey testine göre, 18-28 yaş arasındaki katılımcıların, 51-61 \& 62 ve üzeri yaş grupları arasındaki katılımcılara göre reklamlarda ünlü kullanımı algıları, 40-50 yaş aralığındaki katıımcıların 51-61 yaş grubu aralığındaki katılımcılara göre markaya yönelik tutumları, 18-28 yaş grubu aralığındaki katılııların, 51-61 yaş grubu aralığındaki katılımcılara göre satın alma niyetleri algılarının daha yüksek olduğunu söylemek mümkündür.

Tüketicilerin meslekleriyle, reklamda ünlü kullanım algısı, markaya yönelik tutumları ve satın alma niyetleri anlamlı bir farklılık göstermiştir. $\mathrm{H}_{15}(0,004<0,050), \mathrm{H}_{25}(0,023<0,050)$ ve $\mathrm{H}_{35}(0,000<0,050)$ hipotezlerinin iddaalarının doğruluğu böylece tespit edilmiştir. Gruplar arasındaki farklııkların tespitinde Tukey testinden yararlanılmıştır. Öğrencilerin reklamda ünlü kullanımı algısı ve satın alma niyeti, özel sektör çalışan katılımcılara göre daha hassastır. Tüketicilerin gelir durumlarıyla, reklamlarda ünlü kullanım algısı, markaya yönelik tutumları ve satın alma niyetleri arasında anlamlı bir ilişki olduğu tespit edilmiş olup, $\mathrm{H}_{16}(0,003<0,050), \mathrm{H}_{26}(0,005<0,050)$ ve $\mathrm{H}_{36}$ hipotezleri kabul edilmiştir. Aylık geliri 0-999 TL. olan tüketicilerin reklamda ünlü kullanımı algısı, aylık geliri 5000 TL. ve üzeri olan katılımcılara göre daha yüksektir. Aylık geliri 1000-1999 Tl. olan katılımcıların markaya yönelik tutumları, aylık geliri 5000 TL. ve üzeri olan katılımcılara göre daha hassastır. Tüketicilerin alışverişlerini ilk sırada etkileyen faktörlerle, reklamlarda ünlü kullanımı algısı, markaya yönelik tutumları ve satın alma niyetleri arasında anlamlı bir farklılık saptanmıştır. $H_{17}(0,011<0,050), H_{27}(0,005<0,050)$ ve $H_{37}(0,014<0,050)$ hipotezleri kabul edilmiştir. Alışverişleri ilk sırada etkileyen faktör olarak tespit edilen marka ismi algısı tüketicilerin markaya yönelik tutumlarını, diğer faktörlerden ünlü kullanımı algısı olan katılımcıların markaya yönelik tutumlarına nazaran daha daha çok hassasiyet göstermektedir.

\subsection{Regresyon Analizi}

Tablo 8'de tüketicilerin reklamda ünlü kullanımı algılarının markaya yönelik tutumlarına olan etkisini belirlemek amacıyla regresyon analizi gerçekleştirilmiştir. Katılımcıların reklamda ünlü kullanımı algılarının markaya yönelik tutumlarına olan etkisini olumlu yönde etkilediği ortaya çıkmıștır ( $R$ kare değeri $0,626, F=803,977$ ve $p=0,000<0,001$ ). Model istatistiki olarak markaya yönelik tutumdaki değişikliği anlamlı olarak açıklamaktadır. Reklamda ünlü kullanımı algısı markaya yönelik 
tutumdaki değişikliğin tüketicilerde \%62,6'sını açıklamaktadır. Sabit terim, modeldeki bağımsız değişken olan reklamda ünlü kullanımı algısının sıfır değeri aldığı durumda, bağımlı değişken olan markaya yönelik tutumun alacağı değeri göstermektedir. Sabit terimin Beta katsayısı 1,124'tür. Modele gore, reklamlarda hiç ünlü kullanılmaması durumunda, markaya yönelik tutumun değeri 1,124 olacaktır. Tablo 8'deki ikinci satırda reklamda ünlü kullanımına ilişkin Beta1 katsayısı göülmektedir (Beta1=0,673) Bu değer, bağımsız değişkendeki bir birimlik değişme olduğunda, bağımlı değişkende ne kadarlık bir değişikliğin olacağını gösterir (İslamoğlu ve Alnıaçık, 2013: 355). Yani reklamda ünlü kullanımındaki bir birimlik bir değişimin, markaya yönelik tutumda 0,673 birimlik aynı yönlü bir değişim ortaya çıkaracağı yorumu yapılabilir. $\mathrm{H}_{4}$ hipotezi olan "Tüketicilerin reklamda ünlü kullanımı algısı ile markaya yönelik tutumları arasında anlamlı bir ilişki vardır." iddası böylece kabul edilebilir yorumu yapılabilir.

Tablo 8. Reklamda Ünlü Kullanımının Markaya Yönelik Tutumu Üzerindeki Etkisini Belirlemeye îlişkin Regresyon Analizi Sonuçları

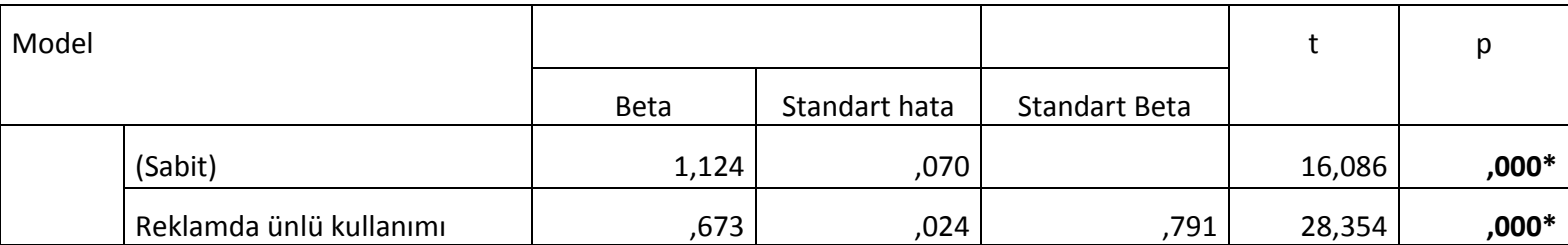

Bağımlı değişken: Markaya yönelik tutum

Tablo 9: Reklamda Ünlü Kullanımının Satın Alma Niyeti Üzerindeki Etkisini Belirlemeye ilişkin Regresyon Analizi Sonuçları

\begin{tabular}{|c|c|c|c|c|c|c|}
\hline \multirow{2}{*}{\multicolumn{2}{|c|}{ Model }} & & & & \multirow[t]{2}{*}{$\mathrm{t}$} & \multirow[t]{2}{*}{$p$} \\
\hline & & Beta & Standart hata & Standart Beta & & \\
\hline & (Sabit) & ,046 & 124 & & ,368 & ,713 \\
\hline & Reklamda ünlü kullanımı & ,799 & ,042 & ,655 & 18,983 & ,000* \\
\hline
\end{tabular}

Bağımlı değişken: Satın alma niyeti

Tablo 9' da tüketicilerin reklamda ünlü kullanımı algılarının satın alma niyetine olan etkisini tespit etmek amacıyla regresyon analizi yapılmıştır. Katılımcıların reklamda ünlü kullanımı algılarının satın alma niyeti üzerinde anlamlı bir etkisi olduğu yorumlanabilir ( $R$ kare değeri $0,429, F=360,369$ ve $p=0,000<0,001$ ). Model istatistiki olarak satın alma niyeti üzerindeki değişikliği anlamlı olarak açıklamaktadır. $\mathrm{H}_{5}$ hipotezi olan "Tüketicilerin reklamda ünlü kullanımı algısı ile satın alma niyetleri arasında anlamlı bir ilişki vardır." ifadesi doğrudur sonucuna varılabilir. Reklamda ünlü kullanımı algısı satın alma niyeti üzerindeki değişikliğin tüketicilerde \%42,9'unu açıklamaktadır. Sabit terimdeki $p$ değeri=0,713>0,001 olduğu için bu durumda Beta katsayısının bir anlam ifade etmediği söylenebilir. İkinci satırda reklamda ünlü kullanımına ilişkin Beta 1 $(0,799)$ katsayısı mevcuttur. Reklamda ünlü kullanımındaki bir birimlik değişimin, satın alma niyeti üzerinde 0,799 birimlik aynı yönlü bir değişime yön vereceği sonucu çıkartılabilir.

Tablo 10: Markaya Yönelik Tutumın Satın Alma Niyeti Üzerindeki Etkisini Belirlemeye İlişkin Regresyon Analizi Sonuçları

\begin{tabular}{|c|c|c|c|c|c|c|}
\hline \multirow{2}{*}{\multicolumn{2}{|c|}{ Model }} & & & & \multirow[t]{2}{*}{$\mathrm{t}$} & \multirow[t]{2}{*}{ Sig. } \\
\hline & & Beta & Standart hata & Standart Beta & & \\
\hline \multirow{2}{*}{1} & (Sabit) &,- 273 & 163 & & $-1,673$ & ,095 \\
\hline & Markaya yönelik tutum & 851 & ,053 & ,593 & 16,155 &, $000 *$ \\
\hline
\end{tabular}


Bağımlı değişken: Satın alma niyeti

Tablo 10 'da tüketicilerin markaya yönelik tutumlarının satın alma niyetine olan etkisini saptamak amacıyla regresyon analizi yapılmıştır. Tüketicilerin reklamda markaya yönelik tutumlarının satın alma niyeti üzerinde anlamlı bir etkisi olduğu sonucuna varılabilir ( $R$ kare değeri $0,352, F=260,973$ ve $p=0,000<0,001$ ). Model istatistiki olarak satın alma niyeti üzerindeki değişikliğin anlamlı olduğunu ifade etmektedir. $\mathrm{H}_{6}$ hipotezi olan "Tüketicilerin markaya yönelik tutumlarıla ile satın alma niyetleri arasında anlamlı bir ilişki vardır" iddasının kabul edilebilir olduğu şeklinde yorumlanabilir. Markaya yönelik tutum satın alma niyeti üzerindeki değişikliğin \%35,2'sini açıklamaktadır. Sabit terimdeki $p$ değeri=0,095>0,001 olduğu için bu durumda Beta katsayısının bir anlam taşımamaktadır. İkinci satırda markaya yönelik tutuma ilişkin Beta $1(0,851)$ katsayısı mevcuttur. Markaya yönelik tutumdaki bir birimlik değişimin, satın alma niyeti üzerinde 0,851 birimlik aynı yönde bir değişime sebebiyet vereceği yorumu yapılabilir.

\section{SONUC}

Geçmişten günümüze kadar olan zaman sürecinde insanoğlu, sergilemiş olduğu tutum ve davranışlarında benzemeye çalıştığı ya da beğendiği bireyleri taklit etme arzusu içindedir. Toplumda önemli bir yere sahip olan kişileri örnek alma isteği özellikle daha sık bir şekilde gözlenmektedir. Bireyler karşılaştıkları farklı süreçlerde bile karar verirken ünlü kişilerin davranış tarzlarını ya da sözlerini benimseyerek hareket etmeye çalışabilirler (İşler, 2014: 130).

Araştırmanın literatür incelemesinden sonra Aydın ilinde ikamet eden ve kolayda örnekleme yöntemiyle belirlenen 18 yaş ve üstü 482 tüketiciye anket çalışması yapılmıştır. Reklamlarda ünlü kullanımı boyutlarının tüketicilerin markaya yönelik tutumları ve satın alma kararları üzerindeki etkileri araştııılmıştır. Ankete katılan tüketicilerin yarısından fazlasını kadınlar oluşturmaktadır. 18-30 yaş aralığındaki tüketicilerin oranı, diğer yaş aralığındaki katılımcılara oranla çoğunluğu temsil etmektedirler. Medeni duruma bakıldığında bekâr tüketicilerin, eğitim durumuna bakıldığında ise lisans mezunu olan tüketicilerin sayısının daha fazla olduğu görülmektedir. Katılımcıların reklamlara en çok kitle iletişim araçlarından internette rastladıklarını, TV izleme sıklıklarının ise yüksek bir oranla günde 1-2 saat olduğu tespit edilmiştir. Bu konularda yapılan önceki çalışmalara bakıldığı zaman özellikle TV reklamlarında ünlü kullanımına sıklıkla rastlanmaktadır. Teknolojinin ilerlemesiyle reklamların özellikle internet ortamında önemi daha da artmış olup bu durum da tüketicilerin satın alma davranışlarını oldukça etkilemeye başlamıştır.

Araştırmada reklamda ünlü kullanımının dört boyuttan oluştuğu saptanmıştır. Bu boyutlar ünlünün çekiciliği, ünlünün güvenilirliği, ünlünün uzmanlığı ve ünlü-marka uyumu olarak gruplandırılmıştır. Reklamlarda ünlü kişilerin kullanılması diğer reklamlara göre daha dikkat çekici ve etkilidir. Çekicilik modeli markanın unutulmaması, markaya yönelik tutum ve satın alma niyeti gibi konularda insanların daha çok dikkati çeker yorumu yapılabilir ve çoğu araştırmaya bakıldığında da reklamlarda fiziksel yönden çekici ünlülerin kullanılmasının bu konularda tüketiciler üzerinde olumlu izler bıraktığı sonuçlarına ulaşılmıştır. Ünlünün tüketicileri cezbetmesi ne kadar tüketicilerin dikkatini çekerse reklamların da onların üzerinde bırakacağı olumlu etki de o kadar yüksek olacaktır. Tüketiciler reklamlarda görmek istediği ünlünün fiziksel yönden zihinlerinde olumlu etkiler bırakmasını tercih ederler. Bu görmek istedikleri pozitif durum da onların davranışlarını etkileyecektir. Fiziksel yönden çekici bulunmayan bir ünlünün markanın tercih edilmesini de olumsuz yönde etkileyebilir. Bazı çalışmalara bakıldığında çekicilik boyutunun satın alma niyeti üzerindeki etkisi tam olarak kesinleşmemiştir ve hala bu konuda belirsiz bir durum söz konusudur. Fiziksel çekiciliğin tek başına yeterli olmadığı, reklamlarda kullanılan ünlüye ilişkilendirilebilecek farklı özelliklerin de olması gerektiği yorumu yapılabilir. Ünlünün güvenilirliği boyutuna bakıldığında, tüketiciler reklamda kullanılan ünlüye karşı itimat etmek isterler. Onların kullandıkları kelimelerle reklamda verdikleri mesaj arasında bir bağ kurmaya çalışırlar. Burada dürüstlük kavramı önemli bir rol oynamaktadır. Her tüketicinin algısı ne kadar farklı olsa da eğer ünlü halk tarafından güvenilir bir imaj çizmişse algılanan mesaj da olumlu olacaktır. Reklamlarda kullanılan ünlünün uzmanlığı boyutunda ise, ünlünün tüketiciler tarafından o konuda ne kadar tecrübeli ve bilgili olarak görüldüğü ifade edilmektedir. Tüketici ünlünün o marka hakkında bilgi sahibi olduğuna, markayı kendisinin de deneyip önerdiğine ve markanın da ünlünün kendi alanında yetkin olduğunu düşünerek reklamlarda o ünlüyü oynattığına inandıysa reklamı ikna edici bulup marka hakkında pozitif düşüncelere sahip olması kaçınılmaz bir durum olabilir. Literatür incelendiğinde, çekicilik, güvenilirlik ve uzmanlık boyutları bir bütün olarak kaynak inanılırlığı modelinde toplanmakta ve tek boyutlu olarak ifade edilmektedir. Dördüncü boyut olan ünlü - ürün uyumuna bakıldığında, ünlünün özelleriyle ürünün özellikleri arasında bir ahengin oluşması gerektiği varsayılmaktadır. Ünlünün özellikleriyle kastedilen fiziksel çekicilik, güvenilirlik, uzmanlık ya da diğer başka özellikler olabilir. Yapılan araştırmalarda, ünlünün özellikleriyle reklamlarında oynadıkları ürün arasında bir uyumun olup olmadığına bakılmıștır. Sonuçlara bakıldığında, ünlünün tüketiciler tarafından tek boyutta toplandığını varsaydığımız inanırlık (çekicilik, güvenilirlik ve uzmanlık) modeline uyduğu takdirde markanın daha kolay hatırlanması ve markaya karşı olan tutumun olumlu olduğu görülmektedir. Ünlü-ürün eşleşmesi ne kadar birbirleriyle bağlantılı olursa yapılan reklamların daha etkili olduğu ve tüketicilerin ünlüye olan inancının daha yüksek olacağı yorumu yapılabilir. 
Tüketicinin cinsiyeti ile tüketicilerin reklamlarda ünlü kullanımı algısı, markaya yönelik tutumları ve satın alma niyetleri arasında anlamlı bir farklılı̆ın bulunmadığı tespit edilmiştir. Literatürdeki araştırmalara bakıldığı zaman, özellikle reklamda kullanılan ünlünün cinsiyet farklıı̆̆ının markaya karşı tutum ve satın alma niyeti üzerinde daha belirleyici bir rol oynadığı tespit edilmiştir. Tüketicilerin medeni durumlarıyla reklamlarda ünlü kullanımı algısı ve satın alma niyeti arasında anlamlı bir ilişki olduğu sonucuna varılmıştır. Bekar olan katılımcılar, evli olan katılımcılara göre bu iki konuya karşı daha yüksek bir ilgiye sahiptirler. Toplumumuzda evlilik müessesinin hassas bir yapıda olmasından dolayı reklamlarda ünlü kullanımı bile zaman zaman çiftler arasında kıskançıı tartışmalarına konu olabilecek duruma bile geldiği söylenebilir. Çiftlerden birinin reklamda çıkan ünlüye karşı olan beğenisi açıkça dile getirmesi, diğer eşin markaya karşı olumsuz bir tutum sergilemesine yol açabilir. Bekar insanların kendilerini daha özgür bir yapıda hissetmesinden dolayı bu konuda daha esnek bir düşünce yapısına sahip olduğu sonucuna varılabilir. Tüketicilerin öğrenim durumlarıyla reklamlarda ünlü kullanımı algısı arasında anlamlı bir ilişki olduğu tespit edilmiş olup markaya yönelik tutumları ve satın alma niyeti arasında anlamlı bir farklılığa rastlanmamıştır. Tüketicilerin yaş değişkeni ile reklamda ünlü kullanımı algısı, markaya yönelik tutumları ve satın alma niyetleri arasında anlamlı ilişkiler olduğu saptanmıştır. Genç tüketicilerin, yaşı ilerlemiş tüketicilere göre reklamda ünlü kullanımı konusunda daha iyimser bir bakış açısına sahip olduğu söylenebilir. Teknolojinin ilerlemesiyle birlikte internetin hayatımızın her alanında var olduğu yadsınamaz bir gerçektir. Reklamların artık sadece televizyon ve gazetelerde değil, internet siteleri ve sosyal medya da daha çok gösterilmeye başlandığı görülmektedir. Genç kuşakların internet kullanım oranı, yaşı ilerlemiş tüketicilere göre daha yüksektir. Bununla birlikte değişen alışveriş alışkanlıkları, ürünler arasındaki farklııkların azalması ve parçalanmış pazarlara dönüşüm gibi yeni pazar dinamikleri ortaya çıkmıştır. Hızlı gelişen teknoloji sayesinde bu değişiklerin etkileri özellikle genç kuşaklar üzerinde görülmektedir. Bir pazarlama stratejisi olarak nitelendirilen reklamlarda ünlü kullanımı da işletmeler açısından bir rekabet aracı olarak görülmektedir. Sürekli değişen pazar dinamikleri içinde, reklamda kullanılan ünlünün genç kuşaklar tarafından benimsenmek istenmesi, taklit edilmesi kaçınılmazdır. Rekabetin bu kadar sert olduğu bir ortam ve genç kuşakların yeni gelişmeleri de sürekli talip ettiği de düşünülürse ünlünün inanırlığı ve markayla olan eşleşmesinin de yeni pazar dinamikleriyle bütünleşmiş olması beklenmektedir. Çalışmada aynı zamanda genç tüketicilerin, yaşı ilerlemiş olan tüketicilere göre satın alma niyetlerinin daha fazla olduğu belirlenmiştir. Yenilikler artmaya başladıkça, hergün yeni bir sektör gelişmekte, böylece eski pazarlama alışkanlıkları unutulmaya başlanmaktadır. Değişime daha çabuk adapte olanların istek ve intiyaçları işletmeler tarafından daha kolay tespit edilebilir hale gelecektir. Orta yaş grubunun, yaşı ilerlemiş olan tüketicilere göre markaya yönelik olan tutumları daha pozitif olduğu söylenebilir. Orta yaş grubundaki ebeveynler, kendi çocuklarının (genç tüketici grubu) istek ve ihtiyaçlarını karşılayabilmek ve onlarla olumlu ilişkiler kurabilmek için bu konuda daha iyimser bir bakışa sahiptirler. Katılımcıların meslek gruplarıyla, reklamda ünlü kullanım algısı, markaya yönelik tutumları ve satın alma niyetleri arasında anlamlı bir ilişki olduğu söylenebilir. Genç kuşak temsilcisi olan öğrencilerin reklamda ünlü kullanımı algısı ve satın alma niyeti, özel sektör çalışan katılımcılara nazaran daha yüksektir. Gelir durumu çok az olan tüketicilerin markaya yönelik tutumları, gelir durumu çok fazla olan tüketiciye göre daha yüksek bir ilgisi olduğu yorumu yapılabilir. Gelir durumu çok az olan grubun çoğu daha yeni mezun olan veya yeni işe başlamış olan genç tüketicileri kapsamaktadır. Sonuçlara bakıldığı zaman değişkenleri oluşturan grupların çoğunun genç kuşak temsilcilerinden oluştuğu gözlenmektedir. Reklamda ünlü kullanımının tüketicilerin markaya yönelik tutumları ve satın alma niyeti üzerinde olumlu bir etkisinin olduğu yorumu yapılabilir. Ayrıca tüketicilerin markaya yönelik tutumlarının satın alma niyeti üzerinde anlamlı bir etkisi olduğu söylenebilir. Daha önceden bahsedildiği gibi, reklamlarda kullanılan ünlünün fiziksel yönden çekici olması, halk tarafından dürüst bulunması, tanıtımını yaptığı marka hakkında bilgi ve deneyim sahibi olması, karakteristik özellikleriyle ürünün özelliklerinin uyuşması gibi kriterler markanın akılda kalmasına ve tekrardan hatırlanmasına sebebiyet verecektir. Zihinde olumlu bir iz bırakan markanın tercih edilmesi de muhtemel olacaktır ve bu durum da satın alma niyetinin oluşmasına neden olacaktır.

Sonuç olarak, reklamlarda ünlü kullanımının işletmelerin rekabet etmeleri açısından onlar için çok önemli bir pazarlama stratejisi olduğu söylenebilir. Reklamda kullanılacak ünlünün seçimine özellikle dikkat etmek gerekmektedir. Tüketicilerin ünlüleri taklit etme isteği kaçınılmaz bir durum olmasından dolayı ünlünün çekiciliği modeli oldukça önem arzetmektedir. Reklamda verilen mesajın etkili olması ünlünün çekici olmasına dayanır. Seçilen doğru ünlü, markanın akılda kalmasını, markaya olan bakış açısını ve tüketicinin satın alma niyetini olumlu yönde etkileyerek satışları arttııı. Reklamcıların ünlü seçiminde dikkat etmesi gereken durum ise ünlünün halk tarafından güvenilir ve bilgili bir kişi olarak tanınmasıdır. Tüketiciler reklamda kullanılan ünlünün dürüst olduğuna inanıp onunda marka hakkında bir bilgisi olduğuna inanırsa ünlünün de reklamını yaptığı markayı tercih ettiğini düşünerek o markaya karşı tutumu ve satın alma kararı olumlu yönde ilerler. Ünlü-ürün uyumunun da birbirleriyle ilişkili olması gerekmektedir. Örnek olarak spor ayakkabı marka reklamında, siyasi yönü olan bir kişinin oynatılması sonucunda ortaya bir uyuşmazlık ortaya çıkacak ve bu durum da tüketiciler tarafından olumsuz karşılanacaktır. Reklamlarda ünlü kullanımı markaya yönelik tutumu ve satın alma niyetini olumlu yönde etkilemektedir. Markaya yönelik tutumun da satın alma niyetini pozitif yönde etkilediği bu çalışma dahil olmak üzere birçok çalışmada da etkilediği ortaya konmuştur. Tüketiciler tarafından benimsenmemiş bir ünlünün reklamlarda oynatılmış olması, hem markanın imajını olumsuz yönde etkileyecek hem de satışların düşmesine sebebiyet verecektir. İşletmelerin rekabet avantajı yakalayabilmeleri gereken bu dünyada bu konuya özellikle hassasiyet gösterilmesi gerekmektedir. 
Bu araştırma ile Aydın ilindeki tüketicilerin reklamlardaki ünlü kullanımı ile ilgili tutumları belirlenmeye çalışılmıştır. Bu bağlamda, araştırmanın reklamlarında ünlü kullanmayı düşünen markalara, reklam şirketlerine, ajanslara, akademisyenlere ve konu ile ilgilenen herkese yardımcı olacağı beklenmektedir. Gelecekte bu konuyla ilgili çalışma yapmak isteyen akademisyenler, farklı coğrafi bölgelerdeki tüketicilerin bu konudaki tutumlarını ölçebilir. Yine reklamda ünlü kullanımı ile farklı değişkenlerin ilişkisini ortaya koyabilir.

\section{KAYNAKLAR}

Agrawal, J., \& Kamakura, A. W. (1995). The economic worth of celebrity endorsers: An event study analysis. Journal of Marketing, vol. 59, no. 3, p. 56-62.

Albar, O. B. ve Oksüz, G. (2013). The effect of using famous people to creating brand awareness ads to consumers: A research in the city of Giresun. International Journal of Social Science, vol. 6, no. 8, p. 417-431.

Alsmadi, S. (2006). The power of celebrity endorsement in brand choice behavior: An empirical study of consumer attitudes in Jordan. Journal of Accounting-Business \& Management, vol. 13, p. 69-84.

Altunışık, R. Yıldırım, E. ve Coşkun, R. (2007). Sosyal Bilimlerde Araştırma Yöntemleri SPSS Uygulamalı. Sakarya: Sakarya Yayıncılık.

Amos, C., Holmes, G., \& Strutton, D. (2008). Exploring the relationship between celebrity endorser effects and advertising effectiveness. International Journal of Advertising, vol. 27, no. 2, p. 209-234.

Bafna, A., Gandhi, P., Jain, A., Dantara, W., Desai, K., Dholakiya, M., Gurnani, N., Gagnani, P., Udhani, D., Keswani, K., \& Kanabar, H. (2016). Influence of celebrity endorsements on the consumer behavior for facial care product. Imperial Journal of Interdisciplinary Research, vol. 2 , no. 5, p. 219-235.

Baldauf, A., Cravens, S. K., Diamantopoulos, A., \& Zeugner-Roth, P. K. (2009). The impact of product-country and marketing efforts on retailer-perceived brand equity: an emprical analysis. Journal of Retailing, vol. 85, no. 4, p. 437-452.

Can, L. ve Serhateri, A. (2016). Sosyal Medya Reklamlarının Markaya Yönelik Tutuma Etkisi: Facebook Üzerinde Bir Uygulama. Balkan ve Yakındoğu Sosyal Bilimler Dergisi, vol. 2, no. 3, p. 16-28.

Deneçli, C. (2015). Reklamlarda Ünlü Kullanımında Cinsiyetin Marka İmajı Üzerine Etkisi. Marmara Üniversitesi Öneri Dergisi, vol. 11, no. 4, p. 337-350.

Erdogan, Z. (1999). Celebrity endorsement: A literature review. Journal of Marketing Management, vol.15, no. 4, p. 291-314

Erkal, E. (2013). Reklamlarda ünlü kullanımının “Satın alma davranışı üzerindeki etkisi”. Yüksek lisans tezi, Selçuk Üniversitesi Sosyal Bilimler Enstitüsü.

Eser, Z., Korkmaz, S. ve Öztürk, A. S. (2011). Pazarlama Kavramlar - İlkeler - Kararlar. Gözden Geçirilmiş ve Güncellenmiş 2. Baskı. Ankara: Siyasal Yayın.

Fleck, N., Korchia, M., \& Roy, L. I. (2012). Celebrities in advertising: Looking for congruence or likability?. Psychology and Marketing, vol. 29, no. 9 , p. 651-662

Gupta, R., Kishore, N., \& Verma, DPS. (2015). Impact of celebrity endorsements on consumers' ad perception: A study of Indian consumers. British Journal of Marketing Studies, vol. 3, no. 8, p. 34-49.

Ha, M. N., \& Lam, H. G. (2017). The effects of celebrity endorsement on customer's attitude toward brand and purchase intention. International Journal of Economics and Finance, vol. 9, no. 1, p. 64-77.

İslamoğlu, H. A. ve Alnıaçık, Ü. (2013). Sosyal Bilimlerde Araştırma Yöntemleri. Gözden Geçirilmiş ve Genişletilmiş 3.Baskı. İstanbul: Beta Yayınları.

İslamoğlu, H. A. ve Altunışık R. (2013). Tüketici Davranışları. Geliştirilmiş ve Gözden Geçirilmiş 4. Baskı. İstanbul: Beta Yayınları.

İşler, D. B. (2014). Televizyon Reklamlarında Ünlü Kişilerin Kullanılmasının Satın Alma Davranışlarına Etkisi: Cinsiyet Ekseninde Bir İnceleme. Süleyman Demirel Üniversitesi Vizyoner Dergisi, vol. 5, no.11, p. 110-134.

Kamins, M. A. (1990). An investigation into the "Match-up" hypothesis in celebrity advertising: When beauty may be only skin deep. Journal of Advertising, vol. 19, no. 1, p. 4-13.

Kurtbaş, I. ve Barut, B. (2010). "Star-Marka" stratejisiyle yapılan televizyon reklamlarının marka farkındalığı ve marka sadakati oluşturma sürecindeki rolü ve etkisi. Galatasaray Üniversitesi İletişim Dergisi, vol. 13, p. 108-144.

Malik, G., \& Gupta, A. (2014). Impact of celebrity endorsements and brand mascots on consumer buying behaviour. Journal of Global Marketing, vol. 27, p. 128-143.

Mathur, K. L., Mathur, I., \& Rangan, N. (1997). The wealth effects associated with a celebrity endorser:The Michael Jordan phenomenon. Journal of Advertising Research, May-June, p. 67-73. 
McCracken, G. (1989). Who is the celebrity endorser? Cultural foundations of the endorsement process. Journal of Consumer Research, vol. 16 , no. 3, p. 310-321.

Muda, M., Musa, R., Mohamed, N. R., \& Borhan, H. (2014). Celebrity entrepreneur endorsement and advertising effectiveness. ProcediaSocial and Behavioral Sciences, vol. 130, p. 11-20.

Mutlu, M. H., Çeviker, A. ve Çirkin, Z. (2011). Tüketici Etnosentrizmi ve Yabancı Ürün Satın Alma Niyeti: Türkiye ve Suriye Üzerine Karşılaştırmalı Analiz. Sosyoekonomi, Ocak-Haziran, no. 1, p. 51-74.

Odabaşı, Y. ve Oyman, M. (2009). Pazarlama Illetişimi Yönetimi (8. Baskı). İstanbul: MediaCat.

Öztürk, C. M. ve Savaş, T. A. (2014). Sosyal Amaca Yönelik Pazarlama Reklamlarının Markaya Yönelik Tutum ve Satınalma Niyetine Etkisi: Anadolu Üniversitesi Öğretim Elemanlarına Yönelik Bir Uygulama. E-Journal of Yasar University, vol. 9, no. 35, p. 6099-6260.

Peltekoğlu, B. F. (2010). Kavram ve Kuramlarıyla Reklam. İstanbul: Beta Yayıncılık.

Pornpitakpan, C. (2003). Validation of the celebrity cndorsers' credibility scale: Evidence from Asians. Journal of Marketing Management, vol. 19 , no. 1-2, p. $179-195$.

Sertoglu, E. A., Catlı, O., \& Korkmaz, S. (2014). Examining the effect of endorser credibility on the consumers' buying intentions: An empirical study in Turkey. International Review of Management and Marketing, vol. 4, no. 1, p. 66-77.

Spry, A., Pappu, R., \& Cornwell, B. T. (2011). Celebrity endorsement, brand credibility and brand equity. European Journal of Marketing, vol. 45 , no. 6 , p. $882-909$.

Till, D. B., \& Busler, M. (2000). The match-up hypothesis: Physical tttractiveness, expertise, and the role of fit on brand attitude, purchase intent and brand beliefs. Journal of Advertising, vol. 29, no. 3, p. 1-13.

Waldt, D., Loggerenberg, M., \& Wehmeyer, L. (2009). Celebrity endorsements versus created spokespersons in advertising: A survey among students. Sajems Ns, vol. 12, no. 1, p. 100-114.

Wang, W. S., Kao, H. G., \& Ngamsiriudom, W. (2017). Consumers' attitude of endorser credibility, brand and intention with respect to celebrity endorsement of the airline sector. Journal of Air Transport Management, vol. 60, p. 10-17.

Wei, P., \& Lu, H. (2013). An examination of the celebrity endorsements and online customer reviewsinfluence female consumers' shopping behavior. Computers in Human Behavior, vol. 29, p. 193-201.

Yıldırım, M., Boztaş, K. R. ve Temizkan, M. (2014). Reklamlarda kullanılan ünlü ve marka arasındaki uyumun ünlünün inanırlık ve çekiciliğinin tüketicinin markaya karşı tutumuna etkisi. Bitlis Eren Üniversitesi Sosyal Bilimler Enstitüsü Dergisi, vol. 3, no. 1, p. 1-20. 